\title{
ANTIOXIDANT ACTIVITY FROM ETHANOL EXTRACT OF RED SEAWEED (Galaxaura rugosa)
}

Bhayu Gita Bhernama*, Witri Maulidy Ayu, dan Cut Nuzlia

Program Studi Kimia Fakultas Sains dan Teknologi Universitas Islam Negeri Ar-Raniry Banda Aceh

Jln Syeikh Abdur Rauf Kopelma Darussalam, Banda Aceh, 23111

\section{ARTICLE INFO}

Article history:

Received 16 Mar 2021,

Revised 20 Mei 2021

Accepted 22 Jul 2021

Available online 30 July 2021

Keywords:

$\checkmark$ Antioxidants

$\checkmark$ Galauxara Rugosa

$\checkmark \quad$ Phytochemicals

$\checkmark \quad D P P H$

*corresponding author: deta.chavez1678@gmail.com Phone: +6285274105116;

Doi:

https://doi.org/10.31938/jsn.v $\underline{11 \mathrm{i} 2.309}$

\begin{abstract}
Antioxidants are compounds that can delay, reduce, slow down or inhibit oxidation reactions from free radical reactions. Antioxidants donate electrons to unstable free radicals so that these free radicals can be neutralized to not interfere with the body's metabolic processes. Red seaweed Galaxaura rugosa has potential as an antioxidant. The study aimed to determine the antioxidant activity of the ethanol extract of red seaweed Galaxaura rugosa against DPPH free radicals based on the IC50 value. Phytochemical testing and determination of antioxidant activity were carried out using the DPPH method (2,2-diphenyl-1picrylhydrazyl), which was carried out quantitatively using a UV-Vis spectrophotometer. The results of the phytochemical screening of red seaweed ethanol extract contained alkaloids, flavonoids, saponins, steroids, and polyphenols and the IC50 value of red seaweed ethanol extract was 4.59 ppm, while the positive control for Vitamin C was 6.64 ppm. It was concluded that the ethanolic extract of red seaweed Galaxaura rugosa in the South Aceh District had high antioxidant potential, as evidenced by the small IC50 value of $<50 \mu \mathrm{g} / \mathrm{mL}$.
\end{abstract}

\section{ABSTRAK \\ Aktivitas antioksidan dari ekstrak etanol rumput laut merah Galaxaura rugosa}

Antioksidan merupakan senyawa yang mampu menunda, memperkecil, memperlambat atau menghambat reaksi oksidasi dari reaksi radikal bebas. Antioksidan menyumbangkan elektron kepada radikal bebas yang tidak stabil sehingga radikal bebas ini dapat dinetralkan agar tidak mengganggu jalannya proses metabolisme tubuh. Rumput laut merah Galaxaura rugosa berpotensi sebagai antioksidan. Penelitian ini bertujuan untuk menentukan aktivitas antioksidan ekstrak etanol rumput laut merah Galaxaura rugosa terhadap radikal bebas DPPH berdasarkan nilai $\mathrm{IC}_{50}$. Pada penelitian ini dilakukan pengujian fitokimia dan penentuan aktivitas antioksidan menggunakan metode DPPH $(2,2$ difenil-1-pikrilhidrazil) yang dilakukan secara kuantitatif menggunakan spektrofotometer UV-Vis. Hasil dari skrining fitokimia ekstrak etanol rumput laut merah mengandung senyawa alkaloid, flavonoid, saponin, steroid dan polifenol serta nilai $\mathrm{IC}_{50}$ ekstrak etanol rumput laut merah sebesar $4,59 \mathrm{ppm}$ sedangkan kontrol positif Vitamin C sebesar 6,64 ppm. Ekstrak etanol rumput laut merah Galaxaura rugosa di Kabupaten Aceh Selatan memiliki potensi antioksidan yang tinggi. dibuktikan dengan nilai $\mathrm{IC}_{50}$ yang yang kecil yaitu $<50 \mu \mathrm{g} / \mathrm{mL}$.

Kata kunci: Antioksidan, Galauxara rugosa, Fitokimia, DPPH 


\section{PENDAHULUAN}

Aceh Selatan berada di provinsi Aceh. Aceh Selatan dengan lokasi daerah di pesisir pantai menjadikannya kaya akan sumber daya hayati laut. Sumber daya hayati yang potensial untuk dikembangkan salah satunya yakni rumput laut (Muchlisin et al., 2012). Akan tetapi, pemanfaatan rumput laut masih sedikit, dimana masyarakat Aceh masih menjadikan rumput laut sebagai produk makanan (Ananda, 2019). Salah satu usaha pemanfaatannya adalah budidaya rumput laut. Budidaya rumput laut ini memberikan hasil yang baik apabila dilakukan secara intensif, sehingga dapat meningkatkan produksi dan ekspor rumput laut (Rahmayanti et al., 2018). Selain itu, pemanfaatan lain dari rumput laut adalah sebagai antioksidan alami yang dapat digunakan sebagai bahan tambahan kosmetik dan obat-obatan (Ananda, 2019). Rumput laut merah mempunyai kandungan senyawa polifenol (Ananda, 2019), fenolik dan flavonoid (Yanuarti et al., 2017) berperan sebagai antioksidan alami. Penelitian sebelumnya menyatakan bahwa rumput laut Turbinaria conoides dan Eucheuma cottonii dapat menjadi antioksidan alami yang berpotensi besar (Yanuarti et al., 2017).

Rumput laut merah juga diketahui sebagai salah satu sumber antioksidan yang sangat potensial (Amaranggana \& Wathoni, 2017). Rumput laut merah yang berpotensi sebagai antioksidan yaitu Galaxaura rugosa (Widowati et al., 2014), Eucheuma spinosum (Podungge et al., 2018), Eucheuma cottoni (Ananda, 2019), dan Gracilaria sp (Purwaningsih \& Deskawati, 2020). Galaxaura rugosa termasuk jenis rumput laut merah (Rhodophyta) (Ruslaini, 2016) yang memiliki senyawa metabolit sekunder yang memiliki kemampuan sebagai antioksidan dan antibakteri (Febrianto et al., 2019). Beberapa penelitian terkait dengan antioksidan dari rumput laut merah Galaxaura rugosa telah dilakukan, seperti yang telah dilakukan oleh Widowati et al., (2014), menentukan aktivitas antioksidan dari Galaxaura rugosa mengggunakan pelarut etil asetat memiliki IC50 sebesar 172,67 ppm. Febrianto et al., (2019) melaporkan bahwa rumput laut merah Galaxaura rugosa dari dua pantai gunung kidul menggunakan pelarut metanol memiliki aktivitas antioksidan yang rendah dengan IC50 sebesar 168,76 ppm dan 188,53 ppm. Mahmudah (2018) menyatakan bahwa hasil uji antioksidan menunjukkan hanya
Galaxaura rugosa dari Pantai Newa memiliki potensi sebagai antioksidan.

Alternatif proses pemisahan antioksidan dari bahan alam dapat dilakukan dengan metode maserasi, dikarenakan cara kerja dan peralatan sederhana dan tidak memerlukan pemanasan. Proses ektraksi dengan metode maserasi berpotensi mendapatkan banyak senyawa aktif, meskipun mengandung senyawa yang mempunyai kelarutan terbatas dalam pelarut dan suhu (Nurhasnawati et al., 2017). Selain itu, pengerjaan metode maserasi lebih aman untuk semua senyawa aktif termasuk yang tidak tahan terhadap pemanasan (Hasanah et al., 2016). Hasanah et al., (2016) menyatakan bahwa perhitungan $\mathrm{IC}_{50}$ dengan menggunakan dua macam jenis ekstraksi yaitu maserasi dan refluks. Dari kedua metode tersebut, maserasi menghasilkan nilai $\mathrm{IC}_{50}$ sebesar $164,12 \mathrm{ppm}$ sedangkan refluks memperoleh nilai $\mathrm{IC}_{50}$ sebesar $159,67 \mathrm{ppm}$.

Beberapa penelitian dalam penentuan aktivitas antioksidan menggunakan metode maserasi, sokletasi dan refluks (Nurhasnawati et al., 2017) dengan pelarut yang digunakan metanol, etanol, n-heksan dan kloroform (Senja et al., 2014). Podungge et al., (2018) melakukan ekstraksi rumput laut Eucheuma spinosum untuk proses antioksidan memperoleh nilai $\mathrm{IC}_{50}$ terbaik dengan menggunakan pelarut etanol 97,522 ppm. Purwaningsih \& Deskawati, (2020) menentukan aktivitas antioksidan dari Gracilaria $s p$ dengan metode maserasi, dimana pelarut yang digunakan yaitu etanol, n-heksan dan etil asetat. Dari ketiga pelarut tersebut etanol memiliki nilai $\mathrm{IC}_{50}$ tertinggi sebesar $22.15 \pm 1.63 \mu \mathrm{g} / \mathrm{mL}$. Sari et al., (2015) melaporkan bahwa aktivitas antioksidan dengan metode maserasi diperoleh fraksi etanol paling tinggi ialah alga olahan (AO) memperoleh nilai $\mathrm{IC}_{50} 333,66 \mu \mathrm{g} / \mathrm{mL}$, alga segar (AS) 418,32 $\mu \mathrm{g} / \mathrm{mL}$ dan alga kering (AK) $472,14 \mu \mathrm{g} / \mathrm{mL}$. Bangngalino \& Badai, (2018) melaporkan bahwa hasil penelitian menunjukkan perolehan hasil ekstraksi dengan variansi konsentrasi pelarut yaitu pelarut etanol $55 \%$ menghasilkan ekstrak sebesar $13,95 \%$, pelarut etanol $75 \%$ sebesar $8,71 \%$ dan pelarut etanol $95 \%$ sebesar $17,06 \%$. Sedangkan nilai $\mathrm{IC}_{50}$ untuk setiap konsentrasi ekstrak pelarut adalah 1.179.245 ppm untuk etanol 55\%, 1.190.476 ppm untuk etanol 75\%, dan 3.032.258 ppm untuk etanol 95\%. Analisis GC-MS menunjukkan hasil bahwa untuk ekstrak dengan pelarut etanol 55\% terdeteksi ada 40 senyawa penyusun. Dari hasil tersebut dapat disimpulkan bahwa konsentrasi etanol terbaik 
untuk diekstrak antioksidan dari rumput laut Eucheuma cottoni itu 55\%.

Metode yang sering digunakan dalam penentuan antioksidan adalah metode 1,1diphenil-2-picrylhydrazil (DPPH). Metode DPPH digunakan karena membutuhkan sedikit sampel, metodenya sederhana, cara kerja mudah dan cepat (Pramesti, 2013) serta praktis dan akurat (Suhaling, 2010). Menurut Putri et al., (2020) uji aktivitas antioksidan DPPH lebih efektif dan efisien dibandingkan dengan FRAP. Maesaroh et al., (2017) menyatakan bahwa diantara ketiga metode uji yaitu DPPH, FRAP dan FIC metode DPPH dinyatakan paling efektif dan efisien.

Penelitian mengenai uji aktivitas antioksidan rumput laut merah terus dikembangkan oleh peneliti terutama pada rumput laut merah Galaxaura rugosa. Akan tetapi, analisis aktivitas antioksidan dari rumput laut merah Galaxaura rugosa di Aceh masih sangat sedikit ditemukan. Sehingga perlu dilakukan penelitian tentang analisis aktivitas antioksidan dari rumput laut merah Galaxaura rugosa yang berasal dari Kabupaten Aceh Selatan menggunakan pelarut etanol.

\section{BAHAN DAN METODE}

\section{Bahan dan Alat}

Bahan-bahan yang diperlukan adalah Rumput laut merah Galaxaura rugosa yang berasal dari Aceh Selatan, etanol $\left(\mathrm{C}_{2} \mathrm{H}_{5} \mathrm{OH}\right)$ pa, besi(III) klorida $\left(\mathrm{FeCl}_{3}\right) 1 \%$, asam sulfat $\left(\mathrm{H}_{2} \mathrm{SO}_{4}\right)$ p, serbuk magnesium $(\mathrm{Mg})$, asam klorida $(\mathrm{HCl})$, akuades $\left(\mathrm{H}_{2} \mathrm{O}\right)$. reagen Dragendroff, reagen Mayer, pereaksi Liebermant Burchard dan 1,1-diphenyl-2-picrylhidrazyl (DPPH).

Alat-alat yang diperlukan yaitu toples kaca, tabung reaksi, pipet tetes, rak tabung, botol vial, rotary evaporator, aluminium foil, kertas saring dan spekrofotometri UV-Vis.

\section{Persiapan Rumput Laut Merah Galaxaura rugosa (Veronika et al., 2017). \\ Rumput laut Galaxaura rugosa yang baru dipanen, dibersihkan dari bahan-bahan pengoto., Rumput laut Galaxaura rugosa dikeringkan di ruang terbuka selama 3 s.d 5 hari, dan dipotong dengan ukuran $\pm 2 \mathrm{~cm}$. Setelah itu, material tersebut diblender untuk menghaluskan sampel, dan tuang ke dalam wadah.}

Ekstraksi Rumput Laut Merah Galaxaura rugosa (Mardiyah et al., 2014).

Sampel rumput laut merah Galaxaura rugosa sebanyak 100 gram dimaserasi menggunakan etanol p.a $300 \mathrm{~mL}$ dengan waktu 72 jam. Hasil maserasi disaring, lalu filtrat yang dihasilkan dievaporasi pada suhu $40^{\circ} \mathrm{C}$. Uji fitokimia yang dilakukan berupa uji flavonoid (Nugrahani et al., 2016), alkaloid (Mardiyah et al., 2014), saponin (Najoan et al., 2016), tanin (Nugrahani et al., 2016), polifenol (Ananda, 2019) dan steroid (Ajmi et al., 2017) serta uji aktivitas antioksidannya (Suhaling, 2010).

$\%$ Rendemen $=\frac{\text { Jumlah berat ekstrak berupa pasta }(g)}{\text { Jumlah berat awal }(g)} \times 100 \%$

\section{Uji Aktivitas Antioksidan dan Penetapan $\mathrm{IC}_{50}$ Larutan (DPPH) 1,1-diphenyl-2-picrylhidrazyl}

$15 \mathrm{mg}$ 1,1-diphenyl-2-picrylhidrazyl (DPPH) dilarutkan dengan $100 \mathrm{~mL}$ etanol p.a., lalu disimpan pada botol gelap, ditutup dengan aluminium voil. Larutan disimpan dikulkas pada suhu $-20^{\circ} \mathrm{C}$.

Panjang Gelombang Maksimum Larutan 1,1-diphenyl-2-picrylhidrazyl (DPPH)

$1 \mathrm{~mL}$ Larutan 1,1-diphenyl-2-picrylhidrazyl (DPPH) diencerkan sampai volume $5 \mathrm{ml}$, homogenkan, lalu didiamkan \pm 30 menit. Panjang gelombang maksimum diukur antara 400-600 nm.

\section{Serapan Blanko DPPH}

$5 \mathrm{~mL}$ 1,1-diphenyl-2-picrylhidrazyl (DPPH) dipipet lalu diukur absorban pada panjang gelombang maksimum.

\section{Standar Asam Askorbat (Vitamin C)}

0,1 gram Vitamin C dilarutkan dengan 100 $\mathrm{mL}$ etanol p.a. sehingga didapatkan larutan induk. Larutan standar dibuat dengan konsentrasi 2,4,6, 8 dan $10 \mathrm{ppm}$, kemudian diukur serapan pada panjang gelombang maksimum.

\section{Ekstrak Etanol Rumput Laut Merah Galaxaura rugosa}

Metoda pengukuran aktivitas antioksidan menggunakan metoda DPPH merujuk pada teori yang dilakukan Molyneux, (2004). Radikal bebas yang stabil dari DPPH direaksikan dengan senyawa yang menyumbangkan atom hidrogen, kemudian terjadi reaksi reduksi dari DPPH. Reaksi reduksi ini ditandai dengan adanya perubahan warna violet menjadi kuning pucat. 
Larutan induk 1000 ppm dari ekstrak etanol rumput laut merah Galaxaura rugosa.

Ekstrak etanol rumput laut merah Galaxaura rugosa sebanyak 0,1 gram dilarutkan dalam $100 \mathrm{~mL}$ pelarut etanol, lalu dibuat larutan standar pada konsentrasi 2, 4, 6, 8 dan 10 ppm. Campuran dihomogenkan dan didiamkan selama 30 menit, sehingga terjadi perubahan warna. Serapan masing-masing konsentrasi diukur pada panjang gelombang maksimum. Nilai persentase inhibisi (penghambatan) didapatkan menggunakan perhitungan dibawah ini :

$\%$ Inhibisi $=\frac{\text { Absorbansi Blanko }- \text { Absorbansi Sampel }}{\text { Absorbansi Blanko }} \times 100$

Aktivitas antioksidan ditentukan dari nilai $\mathrm{IC}_{50}$. Nilai IC50 tersebut diperoleh dari persamaan regresi : $\mathrm{y}=\mathrm{a}+\mathrm{bx}$. Nilai $\mathrm{x}=$ nilai $\mathrm{IC}_{50}$ dan nilai $\mathrm{y}=50$ (Ningrum et al, 2017). Nilai $\mathrm{IC}_{50}$ diartikan sebagai konsentrasi sampel yang digunakan untuk menghambat proses oksidasi sebesar 50\% (Nurhasnawati, Handayani, et al., 2017).

\section{HASIL DAN PEMBAHASAN}

\section{Ekstraksi Rumput Laut Merah Galaxaura rugosa}

Ekstrasi rumput laut merah Galaxaura rugosa menggunakan metode maserasi dengan pelarut etanol selama $3 \times 24$ jam menghasilkan rendemen sebesar $0,737 \%$. Proses ekstraksi yang dilakukan selama $3 \times 24$ bertujuan agar komponen-komponen yang terdapat pada bahan dapat terlarut dengan sempurna (Hardiningtyas et al., 2014).

\section{Uji Fitokimia Ekstrak Etanol Rumput Laut Merah Galaxaura rugosa}

Sampel hasil maserasi diambil untuk pengujian fitokimia, kemudian ditambahkan dengan reagen yang sesuai. Hasil uji fitokimia ekstrak etanol rumput laut merah Galaxaura rugosa ditunjukkan pada Tabel 1 dibawah ini.

Hasil uji fitokimia dari ekstrak etanol rumput laut merah Galaxaura rugosa asal Aceh Selatan menunjukkan terdapatnya senyawa metabolit sekunder pada rumput laut merah Galaxaura rugosa berupa alkaloid, flavonoid, saponin, steroid dan polifenol (Tabel 1). Begitu juga dengan rumput laut merah Gracilaria verrucosa, Gracilaria sp dan Eucheuma spinosium yang diambil sebagai pembanding dari beberapa literasi.

Purwaningsih \& Deskawati (2020) dalam artikelnya menjelaskan bawah pelarut etanol memiliki peranan yang penting dalam melarutkan senyawa metabolit sekunder. Hal ini dikarenakan etanol melarutkan senyawa flavonoid dan saponin. Hardiningtyas et al., (2014) juga memaparkan metabolit sekunder yang berperan sebagai antioksidan adalah flavonoid dan juga steroid. Setzer, (2008) menjelaskan metabolit sekunder steroid termasuk dalam jenis antioksidan lipofilik, sedangkan flavonoid termasuk dalam antioksidan hidrofilik dan lipofilik. Antioksidan hidrofilik dan lipofilik memiliki kemampuan dalam melindungi tubuh makhluk hidup dari kerusakan yang disebabkan oleh reactive oxygen species (ROS).

Tabel 1. Hasil uji fitokimia ekstrak etanol beberapa rumput laut merah

\begin{tabular}{llcccc}
\hline No Uji & $\begin{array}{c}\text { Galaxaura } \\
\text { rugosa } \\
\text { (sampel) }\end{array}$ & $\begin{array}{c}\text { Gracilaria } \\
\text { verrucosa } \\
\text { (Febrianto } \text { et } \\
\text { al., 2019) }\end{array}$ & $\begin{array}{c}\text { Gracilaria sp } \\
\text { (Purwaningsih } \\
\text { \& Deskawati, } \\
2020)\end{array}$ & $\begin{array}{c}\text { Eucheuma } \\
\text { spinosum } \\
\text { (Podungge } \text { et } \\
\text { al., 2018) }\end{array}$ \\
\hline 1. & $\begin{array}{c}\text { Alkaloid } \\
\quad \text { a. Dragendrof }\end{array}$ & + & + & & + \\
& $\quad$ b. Wagner & - & & + & + \\
2. Flavonoid & + & + & + & + \\
3. & Saponin & + & + & + & - \\
4. & Tanin & - & - & - & - \\
5. & Triterpenoid & - & + & + & + \\
6. & Steroid & + & - & - & + \\
7. & Polifenol & + & + & - & + \\
\hline
\end{tabular}


Flavonoid sebagai metabolit sekunder juga berperan sebagai antioksidan. Proses reaksi antioksidan yang terjadi pada flavonoid menurut Akhlaghi \& Bandy (2009) dengan menangkap reactive oxygen species (ROS), mencegah terjadinya regenerasi oleh reactive oxygen species (ROS) dan meningkatkan aktivitas antioksidan enzim seluler. Selain itu, flavonoid juga efektif dalam menangkap zat-zat reaktif. Akhlaghi \& Bandy, (2009) juga menjelaskan bahwa flavonoid dapat mencegah timbulnya beberapa penyakit kronis, seperti kanker/tumor, kardiovaskular dan liver.

Menurut (Topçu et al., 2007) steroid juga berperan sebagai antioksidan. Aktivitas steroid selain sebagai antioksidan juga sebagai analgesik dan antitumor.

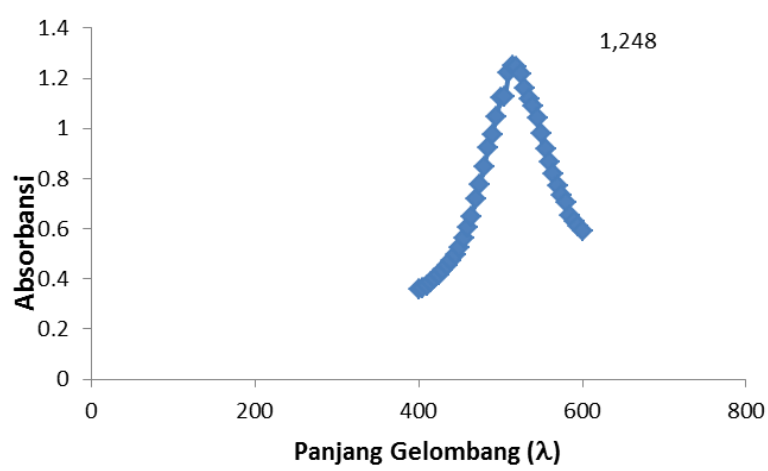

Gambar 1. Kurva Penentuan Gelombang Maksimum $\left(\lambda_{\text {maks }}\right)$ DPPH

\section{Aktivitas antioksidan dari rumput laut merah Galaxaura rugosa}

Penentuan aktivitas antioksidan dari ekstrak etanol rumput laut merah Galaxaura rugosa dilakukan dengan menentukan serapan maksimum dari larutan 1,1-diphenyl-2picrylhidrazyl (DPPH) pada panjang gelombang 400-600 nm. Hasil pengukuran diperoleh serapan maksimum dari larutan 1,1-diphenyl-2picrylhidrazyl (DPPH) sebesar 1,248 pada panjang gelombang $515 \mathrm{~nm}$. Spektrum panjang gelombang maksimum larutan DPPH dapat dilihat pada Gambar 1.Adanya aktivitas antioksidan ditandai dengan perubahan warna ungu menjadi kuning. Perubahan warna ini menimbulkan penurunan nilai serapan sinar dari spektrometometer UV-Vis (Ishak, 2018) yang disebabkan karena proses reaksi reduksi pada senyawa DPPH (Suhaling, 2010).

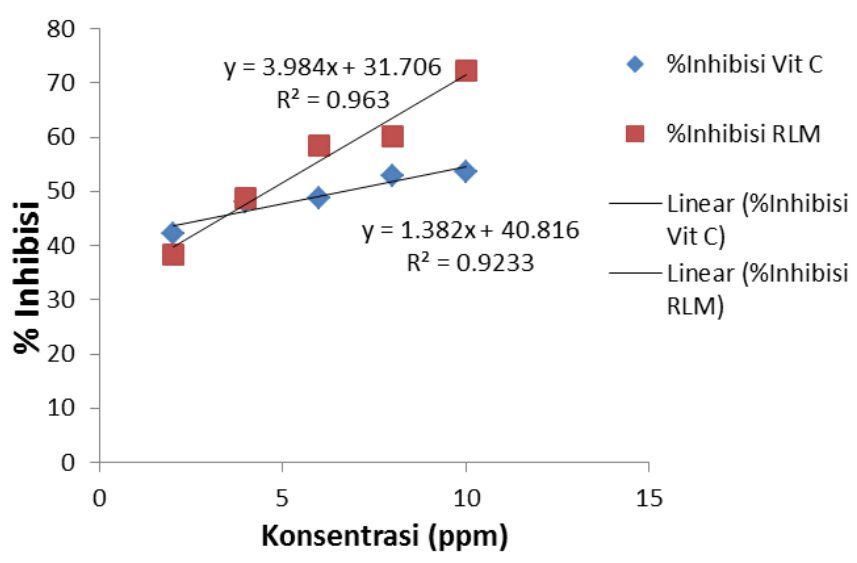

Gambar 2. Kurva Hubungan antara \% Inhibisi dengan Konsentrasi Terhadap Ekstrak Etanol etanol rumput laut merah Galaxaura rugosa dan Kontrol Positif (vitamin C)

Kurva hubungan antara \% inhibisi dengan konsentrasi terhadap ekstrak etanol rumput laut merah Galaxaura rugosa dan kontrol positif menunjukkan nilai $\mathrm{R}^{2}$ etanol rumput laut merah Galaxaura rugosa sebesar 0,96 dan $\mathrm{R}^{2}$ vitamin $\mathrm{C}$ sebesar 0,92 (Gambar 2). Selain itu, juga didapatkan persamaan regresi dari ekstrak etanol rumput laut merah Galaxaura rugosa yaitu y = $3,984 \mathrm{x}+31,706$ dan vitamin $\mathrm{C}$ yaitu $\mathrm{y}=1,382 \mathrm{x}$ $+40,816$. Grafik menunjukkan bahwa saat konsentrasi sampel semakin tinggi maka \% inhibisi juga semakin tinggi. Hal ini sesuai dengan dipaparkan oleh Najoan et al., (2016) dalam artikelnya yang menyatakan hubungan antara persen inhibisi terhadap konsentrasi memiliki hubungan yang berbanding lurus.

Tabel 2. Nilai $\mathrm{IC}_{50}$ Ekstrak Etanol Rumput Laut Merah Galaxaura rugosa dan vitamin C Sampel $\mathrm{IC}_{50}(\mathrm{ppm})$

$\begin{array}{cc}\text { Ekstrak Etanol rumput laut merah Galaxaura rugosa } & 4,59 \\ \text { Vitamin C } & 6,64\end{array}$


Menurut Rivai et al., (2013) IC I0 $_{50}$ merupakan nilai dari besar konsentrasi ekstrak sampel terhadap radikal bebas $50 \%$. Nilai yang ditunjukan pada Tabel 2 sebesar 4,59 ppm memiliki makna semakin kecil nilai $\mathrm{IC}_{50}$ maka semakin semakin kuat dalam menangkap radikal bebas. Hal ini sesuai dengan yang ditulis oleh Molyneux (2004) bahwa kekuatan antioksidan berdasarkan pada kemampuan menangkap radikal bebas. Suatu senyawa dikatakan mampu meredam radikal bebas yang sangat kuat apabila memiliki nilai $<50 \mu \mathrm{g} / \mathrm{mL}$, kuat antara $50-100$ $\mu \mathrm{g} / \mathrm{mL}$, sedang 100-150 $\mu \mathrm{g} / \mathrm{mL}$ lemah > 150 $\mu \mathrm{g} / \mathrm{mL}$ (Molyneux, 2004). Tabel 2 juga menunjukan bahwa ekstrak etanol etanol rumput laut merah Galaxaura rugosa dan vitamin C sebagai kontrol positif mampu meredam radikal bebas dengan aktifitas yang besar. Hal ini sesuai dengan teori yang dikemukakan oleh Podungge et al., (2018) nilai $\mathrm{IC}_{50}$ menunjukkan besarnya aktivitas antioksidan dalam konsentrasi larutan sampel untuk menghambat $50 \%$ radikal bebas 1,1-diphenyl-2-picrylhidrazyl (DPPH).

Radikal bebas terjadi akibat adanya reaksi oksidasi. Radikal bebas yang terbentuk akibat reaksi oksidasi dapat menyerang molekulmolekul lain yang berada di sekitarnya. Oleh karena itu, perlu adanya antioksidan. Antioksidan bereaksi dengan radikal bebas membentuk suatu molekul yang stabil. Antioksidan terlebih dahulu bereaksi dengan radikal bebas dikarenakan sifat antioksidan yang mudah mengalami oksidasi (bersifat reduktor). Semakin kuat antioksidan mengalami oksidasi, semakin efektif antioksidan tersebut (Dwimayasanti, 2018).

\section{KESIMPULAN}

Kesimpulan dari penelitian ini adalah bahwa nilai $\mathrm{IC}_{50}$ dari ekstrak etanol rumput laut merah Galaxaura rugosa yang berasal dari Aceh selatan sebesar 4,59 ppm, dan nilai $\mathrm{IC}_{50}$ dari kontrol positif berupa vitamin $\mathrm{C}$ sebesar 6,64 ppm memiliki aktivitas antioksidan sangat besar.

\section{DAFTAR PUSTAKA}

Ajmi, S., Gani, A., \& Erlidawati, E. (2017). Uji Aktivitas Antioksidan Daun Gulma Siam (Chromoleana odorata L.) dengan Metode 1,1-difenil-2-pikrilhidrazil. Jurnal IPA \& Pembelajaran IPA, I(2), 131-142. https://doi.org/10.24815/jipi.v1i2.9687
Akhlaghi, M., \& Bandy, B. (2009). Mechanisms of flavonoid protection against myocardial ischemia-reperfusion injury. Journal of Molecular and Cellular Cardiology, 46(3), 309-317. https://doi.org/10.1016/j.yjmcc.2008.12.00 3

Amaranggana, L., \& Wathoni, N. (2017). Manfaat Alga Merah (Rhodophyta) Sebagai Sumber Obat dari Bahan Alam. Farmasetika.Com (Online), 2(1), 16. https://doi.org/10.24198/farmasetika.v2i1. 13203

Ananda, M. S. (2019). Aktivitas Antioksidan dari Ekstrak Etanol Rumput Laut Merah (Eucheuma cottonii) di Perairan Kabupaten Aceh Jaya (Vol. 87, Issue 1,2). Universitas Islam Negeri Ar-Raniry.

Bangngalino, H., \& Badai, M. (2018). Analisis Kandungan Dan Aktivitas Antioksidan Pada Rumput Laut Eucheuma Cottoni Yang Diekstraksi Dengan Pelarut Etanol. Prosiding Seminar Hasil Penelitian, 162166.

Dwimayasanti, R. (2018). Rumput Laut : Antioksidan Alami Penangkal Radikal Bebas. Oseana, 43(2), 13-23. https://doi.org/10.14203/oseana.2018.Vol. 43 No. 2.17

Febrianto, W., Djunaedi, A., Suryono, S., Santosa, G. W., \& Sunaryo, S. (2019). Potensi Antioksidan Rumput Laut Gracilaria verrucosa Dari Pantai Gunung Kidul, Yogyakarta. Jurnal Kelautan Tropis, $\quad 22(1), \quad 81$. https://doi.org/10.14710/jkt.v22i1.4669

Hardiningtyas, S. D., Purwaningsih, S.-, \& Handharyani, E.-. (2014). Aktivitas Antioksidan Dan Efek Hepatoprotektif Daun Bakau Api-Api Putih. Jurnal Pengolahan Hasil Perikanan Indonesia, 17(1). https://doi.org/10.17844/jphpi.v17i1.8140

Hasanah, M., Andriani, N., \& Noprizon, N. (2016). Perbandingan Aktivitas Antioksidan Ekstrak Etanol Daun Kersen (Muntingia calabura L.) Hasil Ekstraksi Maserasi dan Refluks. Scientia, 6(2), 84- 
90.

https://doi.org/10.36434/scientia.v6i2.52

Ishak, A. (2018). Analisis Fitokimia dan Uji Aktivitas Antioksidan Biskuat Biji Labu Kuning ( Curcubita sp. ) Sebagai Snack Sehat. In Skripsi Program Studi Ilmu Gizi, Fakultas Kesehatan Masyarakat, Universitas Hasanuddin, Makassar. Universitas Hasanuddin.

Maesaroh, K., Kurnia, D., \& Al Anshori, J. (2017). Perbandingan Metode Uji Aktivitas Antioksidan DPPH, FRAP dan FIC terhadap Asam Askorbat, Asam Galat dan Kuersetin. Chimica et Natura Acta, 6(2), 93-100.

Mardiyah, U., Fasya, A. G., Fauziyah, B., \& Amalia, S. (2014). Ekstraksi, Uji Aktivitas Antioksidan dan Identifikasi Golongan Senyawa Aktif Alga Merah Eucheuma spinosum dari Perairan Banyuwangi. Alchemy, 3(1), 39-46. https://doi.org/10.18860/al.v0i0.2895

Molyneux, P. (2004). The use of the stable free radical diphenylpicryl- hydrazyl (DPPH) for estimating antioxidant activity. 26(2), 9.

Muchlisin, Z. A., Nazir, M., \& Musman, M. (2012). Pemetaan potensi daerah untuk pengembangan kawasan minapolitan di beberapa lokasi dalam Provinsi Aceh: Suatu kajian awal. Depik, 1(1), 68-77. https://doi.org/10.13170/depik.1.1.29

Najoan, J. J., Runtuwene, M. J. R., \& Wewengkang, D. S. (2016). Uji Fitokimia Dan Aktivitas Antioksidan Ekstrak Etanol Daun Tiga (Allophylus Cobbe L.). Pharmacon, 5(1), 266-274. https://doi.org/10.35799/pha.5.2016.11258

Nugrahani, R., Andayani, Y., \& Hakim, A. (2016). Skrining Fitokimia Dari Ekstrak Buah Buncis (Phaseolus vulgaris L) Dalam Sediaan Serbuk. Jurnal Penelitian Pendidikan Ipa, 2(1), 96-103.

Nurhasnawati, H., Handayani, F., \& Samarinda, A. F. (2017). Perbandingan Metode Ekstraksi Maserasi dan Sokletasi terhadap Aktivitas Antioksidan Ekstrak Etanol
Daun Jambu Bol ( Syzygium malaccense L .). Jurnal Ilmiah Manuntung, 3(1), 9195.

Nurhasnawati, H., Sukarmi, S., \& Handayani, F. (2017). Perbandingan Metode Ekstraksi Maserasi Dan Sokletasi Terhadap Aktivitas Antioksidan Ekstrak Etanol Daun Jambu Bol (Syzygium malaccense L.). Jurnal Ilmiah Manuntung, 3(1), 91. https://doi.org/10.51352/jim.v3i1.96

Podungge, A., Damongilala, L. J., \& Mewengkang, H. W. (2018a). Kandungan Antioksidan Pada Rumput Laut Eucheuma Spinosum Yang Diekstrak Dengan Metanol Dan Etanol. Media Teknologi Hasil Perikanan, 6(1), 197-201. https://doi.org/10.35800/mthp.6.1.2018.16 859

Podungge, A., Damongilala, L. J., \& Mewengkang, H. W. (2018b). Kandungan Antioksidan pada Rumput Laut Eucheuma spinosum yang Diekstrak dengan Metanol dan Etanol. Jurnal Media Teknologi Hasil Perikanan, 6(1), 1-5.

Pramesti, R. (2013). Aktivitas Antioksidan Ekstrak Rumput Laut Caulerpa serrulata Dengan Metode DPPH ( 1,1 difenil 2 pikrilhidrazil ). Buletin Oseanografi Marina, 2(April).

Purwaningsih, S., \& Deskawati, E. (2020). Karakteristik Dan Aktivitas Antioksidan Rumput Laut. 23, 10.

Putri, M. D., Arumasi, A., \& Kurniaty, N. (2020). Review Artikel: Uji Aktivitas Antioksidan Ekstrak Daging Buah Semangka dan Albedo Semangka ( Citrullus Lanatus ) dengan Metode DPPH dan FRAP. Prosiding Farmasi, 6(2), 992997.

Rahmayanti, F., Diana, F., \& Kusumawati, I. (2018). Analisis Kesesuaian Perairan untuk Pengembangan Lokasi Budidaya Rumput Laut (Euchema cottonii ) di Perairan Lhok Bubon Kecamatan Samatiga Kabupaten Aceh Barat. Jurnal Akuakultura, 2(1), 26-32. https://doi.org/10.35308/ja.v2i1.773 
Rivai, H., Widiya, E., \& Rusdi, R. (2013). Pengaruh Perbandingan Pelarut Etanol-Air terhadap Kadar Senyawa Fenolat Total dan Daya Antioksidan dari Ekstrak DAun Sirsak (Annona muricata L.). Jurnal Sains Dan Teknologi Farmasi, 18(1), 35-42.

Ruslaini. (2016). Kajian Kualitas Air Terhadap Pertumbuhan Rumput Laut (Gracilaria verrucosa) Di Tambak Dengan Metode Vertikultur. Octopus: Jurnal Ilmu Perikanan, 5(2), 522-527.

Sari, B. L., Susanti, N., \& Sutanto, S. (2015). Skrining Fitokimia dan Aktivitas Antioksidan Fraksi Etanol Alga Merah Eucheuma spinosum. Pharm Sei Res, 2(2).

Senja, R. Y., Issusilaningtyas, E., Nugroho, A. K., \& Setyowati, E. P. (2014). Perbandingan Metode Ekstraksi Dan Variasi Pelarut Terhadap Rendemen Dan Aktivitas Antioksidan Ekstrak Kubis Ungu. 6.

Setzer, W. N. (2008). Non-Intercalative Triterpenoid Inhibitors of Topoisomerase II: A Molecular Docking Study. The Open Bioactive Compounds Journal, 1, 13-17. https://doi.org/10.2174/187484730080101 0013

Suhaling, S. (2010). Uji Aktivitas Antioksidan Ekstrak Metanol KAcang Merah (Phaseolus vulgaris L.) dengan Metode $D P P H$. Universitas Islam Negeri Alauddin Makassar.
Topçu, G., Ertaş, A., Kolak, U., Öztürk, M., \& Ulubelen, A. (2006). Antioxidant activity tests on novel triterpenoids from Salvia macrochlamys. Arkivoc, 2007(7), 195208.

https://doi.org/10.3998/ark.5550190.0008. 716

Veronika, H. H., Mappiratu, M., \& Sumarni, N. K. (2017). Ekstraksi Dan Karakterisasi Ekstrak Zat Warna Rumput Laut ( Eucheuma cottonii ). KOVALEN, 3(1), 716.

Widowati, I., Lubac, D., Puspita, M., \& Bourgougnon, N. (n.d.). Antibacterial And Antioxidant Properties of The Red Alga Gracilaria Verrucosa From The North Coast Of Java, Semarang, Indonesia. 8.

Widowati, I., Lubac, D., Puspita, M., \& Bourgougnon, N. (2014). Antibacterial And Antioxidant Properties Of The Red Alga Gracilaria Verrucosa From The North Coast Of Java, Semarang, Indonesia. International Journal of Latest Research in Science and Technology, 3(3), 8.

Yanuarti, R., Nurjanah, N., Anwar, E., \& Hidayat, T. (2017). Profil fenolik dan aktivitas antioksidan dari ekstrak rumput laut Turbinaria conoides dan Eucheuma cottonii. Jurnal Pengolahan Hasil Perikanan Indonesia, 20(2), 230-237. 